\title{
Preparation of Encapsulated Sn-Cu@graphite Composite Anode Materials for Lithium-Ion Batteries
}

\author{
Venroy Watson ${ }^{1}$, Yaw Yeboah ${ }^{1}$, Mark Weatherspoon ${ }^{2}$, Jim Zheng $^{2}$, Egwu Eric Kalu, ${ }^{1, *}$ \\ ${ }^{1}$ Department of Chemical and Biomedical Engineering, FAMU-FSU College of Engineering, 2525 \\ Pottsdamer St., Tallahassee, FL 32310 \\ ${ }^{2}$ Department of Electrical and Computer Engineering, FAMU-FSU College of Engineering, 2525 \\ Pottsdamer St., Tallahassee, FL 32310 \\ "E-mail: ekalu@eng.famu.fsu.edu
}

doi: $10.20964 / 2018.08 .39$

Received: 20 March 2018 / Accepted: 17 May 2018 / Published: 5 July 2018

\begin{abstract}
Electroless encapsulation of graphite particles with copper-tin alloy ( $\mathrm{Sn}-\mathrm{Cu} @$ graphite) is demonstrated as a feasible anode preparation method that is cost effective and provides both high cyclability and reversible capacity. Heat treatment of the electroless composites at $200{ }^{\circ} \mathrm{C}$ yielded $\mathrm{Sn}-\mathrm{Cu} @$ graphite anode composites with a $20 \mathrm{wt} . \%$ Sn loading, specific surface area of $22.5 \mathrm{~m}^{2} / \mathrm{g}$ and a $1^{\text {st }}$ discharge capacity of $1074 \mathrm{mAh} / \mathrm{g}$ at $0.2 \mathrm{C}$ rate. In contrast, the graphite substrate particles used for the encapsulation has a surface area of $2.34 \mathrm{~m}^{2} / \mathrm{g}$ ) and a $1^{\text {st }}$ cycle discharge capacity of $327 \mathrm{mAh} / \mathrm{g}$ at $0.2 \mathrm{C}$ rate. At the $300^{\text {th }}$ cycle, these capacities decreased to $\sim 400 \mathrm{mAh} / \mathrm{g}$ and $208 \mathrm{mAh} / \mathrm{g}$ for the $\mathrm{Sn}$ $\mathrm{Cu} @$ graphite and graphite substrate, respectively. Above 300 cycles, the electroless encapsulated Sn$\mathrm{Cu} @$ graphite anode maintained a capacity higher than that determined experimentally and theoretically for graphite. The electrochemical impedance and cyclic voltammetric results demonstrate that the electroless encapsulated Sn-Cu@graphite anode has very low resistance and high reversible redox reactions. The higher capacity and long term cycling (> 300 cycles) achieved with the electroless composite anodes are attributed to the buffering effect of the electroless $\mathrm{Cu}$ in the $\mathrm{Sn}-\mathrm{Cu}$ alloy encapsulating graphite particles, Sn-Cu@graphite's higher surface area $\left(22.5 \mathrm{~m}^{2} / \mathrm{g}\right)$, and curvature of the graphite particles. The electroless encapsulated $\mathrm{Sn}-\mathrm{Cu}$ graphite composite anode materials with extended cycling have potential application for the anode of Li-ion battery.
\end{abstract}

Keywords: Copper tin alloy, Tin oxide, Anode, Lithium ion battery electrode

\section{$\underline{\text { FULL TEXT }}$}

(C) 2018 The Authors. Published by ESG (www.electrochemsci.org). This article is an open access article distributed under the terms and conditions of the Creative Commons Attribution license (http://creativecommons.org/licenses/by/4.0/). 